\title{
The Determinants of the Presence of Independent Directors in French Board Companies
}

\author{
Ibtissem CHOUCHENE, Ph.D. \\ Higher Institute of Management, Sousse, Tunisia \\ E-mail: ibtissemchouchane@yahoo.fr
}

\begin{abstract}
The purpose of this paper is to study the determinants of the presence of independent directors on boards of directors. Based on the agency theory, we study the different factors influencing the nomination of independent directors. The tests were applied to a sample of 79 companies belonging to the SBF120 index from 1999 to 2001 . Using an OLS data regression framework, the findings show that the ownership structure and the size of the company determine the independence of the board from the management. The results indicate that when the part of capital represented on the board and held by the coalition of control is low, the presence of independent directors is more important. Also, the presence of the independent directors is significantly and positively determined by the participation of institutional investors and the size of the firm. However we do not find evidence of the influence of the leadership structure and the leverage on the independence of the board.
\end{abstract}

Keywords: Corporate governance, Independent directors, Ownership structure, Agency conflicts, Board

\section{Introduction}

The boards of listed companies have been the subject of much criticism during the ninety and ninety-ten following a series of bankruptcies occurred during those years. These failures have led many authors to question the effectiveness of corporate governance mechanisms and particularly the effectiveness of the board of directors. The boards were criticized as being insufficiently vigilant in protecting the interests of shareholders and companies should be arranged according to Jensen (1993), in order to properly play their missions.

In France, the role of independent directors took considerable extent, particularly after the first and second Viénot report published in France in 1995 and 1999 and the publication of the report Bouton in 2002. These reports have defined the concept of independence of directors and have highlighted the need for their presence in sufficient numbers. The second report Viénot specifies that "A director is independent of the management of the company when it has no relationship whatsoever with the company or its group to affect the exercise of his freedom of judgment" and recommends a presence at least a third. Given the importance of having independent directors, the Bouton Report, found it necessary to raise their proportion to half for companies with dispersed capital and without controlling shareholders.

Several studies have analyzed the factors that determine the independence of the board of directors in the Anglo-Saxon contexts. In France, despite the large number of studies on the board of directors (Charreaux and Pitol Belin, 1985, 1990; Godard and Schatt, 2002, 2005), few, are those which analysed the factors which explain the presence of independent directors. Only studies of outside directors dominate the discussions. The purpose of this study is to identify the factors that determine the presence of independent directors in boards of directors of French listed companies. We have examined the influence of the ownership structure, board size, leadership structure, the size of the company on the independence of the board. The tests were applied to a sample of 79 companies belonging to the SBF120 index from 1999 to 2001. The results suggest that ownership concentration, the size of the company and institutional investors activism explain the presence of independent directors inside french board companies.

The interest of this study in the French context is multiple: First, tests were conducted on a sample of French companies whose governance structures are different from U.S. companies. Indeed, the ownership structure of French company is more concentrated compared to American and British companies whose shareholding is dispersed. Second, one of the specificities of the explanatory model of the presence of the independent directors, it suggests testing the impact of the coalition of control over the composition of the board of directors. The advantage of this new typology of control is, it takes into account, at the same time the structure of the shareholding and the composition board of directors and consequently, the actors that might influence the process of appointment of the independent directors. Our study was also enriched by the consideration of the 
identity of the shareholders for the analysis of the influence of the structure of the shareholding on the presence of the independent directors in boards of directors. Finally, the analyse of the determinants of the presence of the independent directors will allow to understand the underlying incentives in their appointment in the board and shed light on the perception by french firms of the role of the independent directors.

This article is organized as follows: The second section discusses the literature on the factors that determine the presence of independent directors and presents the hypotheses to be tested. The third section describes the sample and the methodology used, followed by results. The analysis and discussion of the results are presented in the fourth section. The last section concludes the study.

\section{The determinants of the presence of independent directors: hypotheses}

Several empirical studies, mainly american's have focused on the contribution of independent directors to the role of supervision by the board. A vast majority of these studies have confirmed the importance of the presence of independent directors, both when studying its impact on the value of the company (Baysinger and Buttler, 1985; Cotter and Silvester, 2003; Pearce and Zahara, 1992; Rosenstein and Wyatt, 1990) or when examining its impact in situations where the interests of managers and shareholders are in conflict as executive compensation, the replacement of leaders or the adoption of poison pills (Borokhovich et al., 1996; Brickley et al., 1994; Hermalin and Weisbach, 1988; Weisbach, 1988).

The existence of the independent directors would allow the board to fill its role of control with efficiency. Based on the framework of the agency theory, several studies analyzed the factors which determine the presence of the independent directors. We propose in what follows to analyze these factors and to derive the hypotheses.

\subsection{Influence of coalition of control}

Charreaux and Pitol Belin (1987) show on a sample of French companies that the propositions of appointment often come from the board of directors, the names of the proposed directors are then approved by the general shareholders' meeting. It is for that reason that Le Maux (2004) proposes that "The research for conflicts between economic agents has to be situated not within the framework of the general assembly but in the heart of the board of directors, the strategic place in terms of power and decision-making”.

LeMaux (2004) proposes a new typology of the control of the company which takes into account the composition of the board of directors and the ownership structure. The goal is, to go beyond the limits of the only consideration of the ownership structure. LeMaux (2004) concludes that the large shareholders and managers form a coalition of control and influence the decisions taken jointly by the Board of Directors. The coalition of control is defined by Le Maux (2004) as being all the economic actors who have the following characteristics: first, an access to all tools and mechanisms for management and control. Such access is impossible for outside shareholders. Second, wide information concerning the controlled company: the coalition of control has a better access to the information compared with all the partners of the firm.

The only study to our knowledge, which took into account the impact of dominant shareholders represented on the board on its composition, is the study of Cotter and Silvester (2003). Most studies, which have focused on the impact of ownership structure on the composition of the board have indeed, tested the impact of the concentration of ownership, measured by the percentage of capital held by large shareholders, on the representation of independent directors (Li, 1994; Prevost, Rao and Hossain, 2002).

Cotter and Silvester (2003) examined the determinants of the independence of the board of directors and supervisory committees formed within it (the audit committee and compensation committee) of large Australian companies. The authors supposed that, in firms where the representation of dominant shareholders is important, the control over the management is more efficient and the percentage of independent directors is lower in such firms. Cotter and Silvester (2003) proved that the representation of shareholders on the board of directors is a significant determinant of the independence of the board. Their presence in the board has a significant negative influence on the independence of the board of directors and committees which it constitutes (audit committee and compensation).

In this perspective, we can assume in the French context that the coalition of control, composed of the large shareholders represented on the board of directors and inside directors can use their power to influence the process of decision on the board and limit the possibilities of implementations of supplementary control mechanisms such as the appointment of independent directors. Therefore,

H1: The capital represented by the coalition control has a negative influence on the presence of independent directors. 


\subsection{The role of institutional investors}

Institutional investors are often viewed as active investors and can use their voting power to encourage good governance practices in firms in which they invest. These investors can put pressure on the direction and lead to manage in accordance with the interests of shareholders, or even cause changes in the systems of controls and incentives (Gillan and Starks, 2003). Thus, Smith (1996) argues that the institutional investor activism can bring the coalition of control to implement organizational changes. He notes that the activism of institutional investors lead to deepest internal changes such as, the appointment of independent directors, separation of the functions of chairman of the board and senior management, the establishment of specialized committees in order to inform the board and improve his functioning and its financial reporting.

The study by Bathala and Rao (1995) on a sample of 261 U.S. companies shows that the participation of institutional investors has a positive impact on the presence of independent directors. These results led the authors to conclude that institutional investors put pressure on companies to increase the number of independent directors. Like Bathala and Rao (1995), O'Sullivan (2000) and Whidbee (1997) also detected a positive relationship between level of institutional ownership and the presence of independent directors on boards of directors of companies studied. These results show that the participation of institutional investors have a significant positive impact on the presence of independent directors in boards of directors. This brings us to test the hypothesis on the French context:

H2: Institutional ownership has a positive influence on the presence of independent directors.

\subsection{Impact of debt}

Under the agency theory, debt plays an important role in limiting agency problems. The contractual nature of the debt, lead top management to reduce their discretionary actions with regard to free cash flows of the company and their motivation to engage in decisions that reduce the value of the company (Jensen, 1986). Then, management consume fewer benefits and become more efficient in order to avoid bankruptcy, lose control and their reputations. Therefore, the debt can reduce agency conflict (Harris and Raviv, 1991).

As part of the study of factors that explain the presence of independent directors, Li (1994) and Prevost et al. (2002) have formulated the hypothesis of the existence of a negative relationship between the presence of independent directors in the board and debt levels. The empirical results have revealed that the relationship between debt and the presence of independent directors is positive. We propose to test the hypothesis in the French context:

\section{H3: The level of debt has a negative influence on the presence of independent directors. Characteristics of the Board of Directors}

Several studies have identified three main features of the board of directors that are likely to influence its composition (Godard, 2002; Mak and Li, 2001; O'Sullivan, 2000; Prevost et al.,2002; Yermarck 1996). We will analyse the relationship between the structure of the board, its size and the tenure of CEO on the presence of independent directors.

\subsubsection{Leadership structure}

When the same person bears the double "cap" of a CEO and Chairman of the Board, domination of the board of directors is widely pronounced, as the chairman is more aligned with the interests of the management than the shareholders (Mak and Li, 2001). The separation of the functions of CEO and chairman of the board, however, improve the ability to control the board of directors (Jensen, 1993).

According to Jensen (1993), delegating decisions to management and the control of decisions to the board is a mean to reduce potential problems of agency conflicts. Therefore, the CEO is responsible for the initiation and implementation of strategic decisions while the board of directors is responsible for ratifying and monitoring decisions taken by the top management. When the chairman of the board of directors is also the CEO, he acquires a larger power which therefore weakens the power of the board of directors and facilitates the entrenchment of the management.

O'Sullivan (2000) argues that the existence of a dominant personality, when both functions are joined, gives a wider power to the CEO and thereby weakening control by the board. O'Sullivan (2000) shows that the separation of the two functions has a positive impact on the presence of independent directors on the board. The results of Prevost Rao and Hossain (2002) prove on a sample of listed companies in New Zealand that the separation of management functions and supervision has a positive influence on the presence of independent directors. Our hypothesis follows: 
H4: The separation of the functions of CEO and chairman of the board has a positive influence on the presence of independent directors on the board.

\subsubsection{Size of the Board of Directors}

Jensen (1993) argues that the boards of large sizes are less likely to function efficiently and are easier to control by the CEO. For Godard (2002), the effectiveness of the board and its composition depends on the size of the board. Yermarck (1996) argues that control by the board of directors is more effective when its size is relatively low. Yermarck (1996) find a negative relationship between the size of the board and company performance.

Li (1994) proved the existence of a significant negative relationship between the size of the Board and the percentage of independent directors on a sample of 390 large manufacturing firms based in Japan, Western Europe and United States. Prevost, Rao and Hossain (2002) test on a sample of companies in New Zealand show no significant results. The study of Mak and Li (2001), however, leads to significant results. It shows on a sample of Singapore that the size of the board of directors has a significant negative impact on the presence of independent directors. We propose to test:

H5: The size of the Board has a negative influence on the presence of independent directors on the board.

\subsubsection{CEO's tenure}

The CEO's tenure reflects its domination and several empirical studies have used the CEO's tenure as a proxy measure of the power of the CEO and his domination of the board. Bathala and Rao (1995) and Prevost et al. (2002) tested the hypothesis of the influence of the CEO's tenure on the presence of independent directors. Bathala and Rao (1995) noted the existence of a significant negative relationship between the proportion of independent directors and the CEO's tenure on a sample of US companies. We propose to test this hypothesis on French companies:

H6: There is a negative association between the percentage of independent directors and CEO's tenure.

\subsubsection{The size of the company}

According to the agency theory, the greater the size of the company, the greater incentives for the establishment of mechanisms for control agency conflicts are important, whether through the use of independent directors or other mechanisms of governance.

Bathala and Rao (1995), Li (1994), O'Sullivan (2000), Prevost et al. (2002) and Whidbee(1997), test the hypothesis of the existence of a positive relationship between the size and proportion of independent directors on board. The results of Bathala and Rao (1995), Li (1994) and O'Sullivan (2000) confirm the hypothesis of the existence of a significant positive relationship between firm size and percentage of independent directors. The preceding analysis leads to the following hypothesis :

H7: The size is positively associated with the percentage of independent directors.

\section{Sample and Research Methodology}

\subsection{Data Collection}

This study uses a longitudinal design to study the factors that explain the presence of independent director. The sample includes listed companies on SBF120's index from 1999 to 2001. However, some adjustments were necessary to exclude:

- Companies that have been subject to mergers acquisition during the study period;

- Banks and insurance companies because they are subject to specific rules.

The final sample consists of 79 companies. The tests were conducted on three consecutive years: 1999,2000 and 2001. The information was collected from annual reports, databases DAFSA, DAFSA Links, Datastream, and Who's Who book which contain the biography of the main French directors and managers.

\subsection{Measurement of variables and methodology}

The explained variable is the proportion of independent directors calculated for each year covered by the study (1999, 2000 and 2001). The percentage of independent directors, coded PINDEP, is the ratio of the number of independent directors by the total number of directors on the board. The evaluation of independence was made on the basis of the definition of the report Bouton (2002).

For independent variables, the influence of the coalition of control is measured with the part of capital held by the coalition of control and coded COALITION. COALITION represents in fact the aggregation of the percentage of the capital held by large shareholders, who do not exercise a managerial function within the 
company and who are represented in the board, with the percentage of the capital held by managers members of the board. The variable INSTIT measure the percentage of capital held by institutional investors. The banks and insurance are excluded. They are indeed, considered as financial shareholders and are generally members of the board but behave differently compared to other institutional investors. The level of debt LEV is measured by the ratio between the total financial debts and total assets of the company the same year studied. The variable proxy of the separation of the functions of chairman of the board and CEO is DUALITY. It is measured by a dichotomous variable that takes the value 1, if there is separation between the function of CEO and chairman of the board and 0 otherwise. The size of the board, coded BOARDSIZE, is measured by the total number of directors on the board members at the end of the year. When the structure of the board is composed of the management board and supervisory board, the size is equal to the sum of the members of the management board and the supervisory board. TENURE refers to the seniority of the CEO; it measures the length of time the CEO has held that position. LOGSIZE is the logarithm of the total consolidated assets of the company.

This study employs multivariate regression analysis in a panel data framework to measure the influence of corporate governance variables on the independence of the board

The general form of model is

\section{PINDEP = a0 + a1COALITION + a2 INSTIT + a3 LEV + a4 TENURE + a5 DUALITY + a6LOGSIZE}

To test the explanatory power of the model developed and identify significant factors, we have used OLS method. The step by step regression method was subsequently used in order to provide the only significant factors explaining the independence of boards of directors.

\section{Results}

\subsection{Overview: Changes in the composition of boards French}

The analysis of changes in the percentage of independent directors as presented in Table 1 shows that the Boards French are increasingly independent from management. Indeed, the average rose from $28.1 \%$ to $29.1 \%$ between 1999 and 2001. In addition, the review of the results shows that the average percentage of directors is below the minimum recommended by the report Viénot II. The report recommends the presence of a minimum of $33 \%$ of independent directors on the board. Some companies, however, far exceeded the minimum recommended by the report Viénot of 1999 to $84.6 \%$ (PINDEP maximum in 2001). Progress still needed for some companies, for which various reports seem to have no effect (the minimum is 0 for 1999, he was also 0 in 2001).

We propose to adopt the following classification:

The boards of companies whose percentage of independent directors is:

-Below the thresholds set by the Viénot II, are considered as non-independent;

-Between $33.33 \%$ and $50 \%$ are considered as independent and;

-More than $50 \%$ are considered to be very independent.

The analysis of the composition of boards over the period 1999 to 2001 shows that companies tend to select a larger number of independent directors (Figure 1). The percentage of boards of directors considered independent and very independent increased over the period of the study. These results can give a brief idea on the awareness by companies in the interest of the implementation of standards relating to corporate governance.

\subsection{Results of uni-variate tests and multivariate tests}

Table 2 presents the correlation matrix for the independent variables. The coefficients for the regression model and related statistics estimated using the Ordinary Least Square method is shown in table 3.

The review of the results shows that the signs of the coefficients are in line with assumptions made for the influence of coalition control $(-0,506 ;-0,493 ;-0,506$ respectively for 1999, 2000 and 2001), participation of institutional investors, the financing structure and the size of the firm ( see Table 2 Panel A, B, C). The sign of the variable structure of the board of directors (DUALITY) and CEO's Tenure (TENURE) differ from one year to another.

The variable size of the board of directors was eliminated from the model because of its strong correlation with the size of the company $(0,659 ; 0,665 ; 0,648$ respectively for 1999, 2000 and 2001). The inclusion in turn of these two variables gives better results when the size of the company is included and the variable size of the board excluded. Also note that the results are broadly consistent over the three years of our study except as regards the variable on the structure of the board of directors DUALITY whose sign varies from year to year. Student tests performed on the coefficients of variables lead to the conclusion that only variables COALITION, 
INSTIT, LOGTAILLE determine significantly the percentage of independent directors on the board of directors of French companies. The tests of regressions step by step also show that these variables retain their explanatory power. The test of Fisher indicates also that the explanatory power of the model is significant of all year of the study.

\section{Analysis and Discussion of results}

The results indicate that the coalition of control composed by the top management who are member of the board and major shareholders represented on the board has a significant influence at the $1 \%$ level on the independence of the board. This implies that when the percentage of capital held by the coalition of control is low, this is the case when capital is dispersed, the need to strengthen systems of control over managers through the independent directors is increasingly felt. However, as the percentage of capital held by the coalition of control increases, the beneficial uses of independent directors are reduced. These findings go hand in hand with those of Charreaux (1997) on the role and composition of boards in family controlled companies.

In France, the analyse by Charreaux Pitol and Belin $(1985,1990)$ of the ownership structure and its influence on the role and characteristics of the Board, have confirmed the impact of the ownership structure on the composition of the board in terms of outside directors. The results showed in fact, that the proportion of outside directors is important when the capital is dispersed. When the ownership structure is concentrated, in the case of companies controlled companies and family, the presence of outside directors is less pronounced. These results also complement the findings of Cotter and Silvester (2003) who studied the determinants of independence of the board and its committees for the control of Australian companies. The authors argued that substantial shareholders are motivated to control the leaders and serve as control mechanisms. Cotter and Silvester (2003) find that greater full board independence is associated with low management ownership and an absence of substantial shareholders.

The impact of institutional investors has been proved both by the results of multiple regressions and with the step by step regression. The percentage of capital held by institutional investors is a significant determinant of the presence of independent directors in boards of directors of French companies at 1\% level. Our results are consistent with the hypothesis of efficiency of control proposed by Pound (1988). These results stem from the fact that independent directors constitute a guarantee of control of leaders' actions. The study of the French case of the company André brought Albouy and Schatt (2004) to conclude that the presence of institutional investors, particularly Anglo-Saxon, is not only important because of their function of financing French companies, but also for the pressure which they exercise on the management and on the major shareholders, who are tempted to neglect the interests of minority shareholders.

The hypothesis of the influence of the size of the company, variable proxy of the intensity of conflict agency, was confirmed. The size of the company appears to be a significant determinant of the presence of independent directors. These results suggest that as the size of the company increases, the agency conflicts between shareholders and executives increase; the use of independent directors is therefore a means to constrain the latitude of managers. Regarding other variables, the results of multiple regressions showed no significant results. This concerns the level of debt, CEO's tenure and the structure of the board.

\section{Conclusion}

The role of independent directors in improving the effectiveness of control has been the subject of lengthy discussions both in academic literature and in the business environments. The aim of this study is to analyse factors that determine the presence of independent directors in boards of directors of French companies. The study results show that the coalition of control has a negative influence on the presence of independent directors. In addition, empirical tests show that when the participation of institutional investors is important, firms are more likely to appoint independent directors. The presence of independent directors is also positively associated with the size of the company. Overall, these results support the conclusion that the existence of strong conflicts of interest between shareholders and executives explain the presence of independent directors on the boards of French companies. The percentage of independent directors is indeed, more important in large companies and highly diluted capital. The appointment of administrators is also a response to the requirements of institutional investors. The principles of corporate governance constitute a criterion of investment for institutional investors. Therefore, companies are more likely to appoint independent directors in order to attract institutional investors and bring them into confidence on the credibility of their management control.

Finally, this study has many implications for theory and practice. The analyse of the determinants of the presence of the independent directors allow to understand the underlying incentives of their appointment in the board and shed light on the perception by the firms of the role of the independent directors. Also, this research provides 
insights on the composition of French boards. It shows that the appointment of independent directors is a strong mechanism to control agency conflicts. Thus, it offers insights to policy makers interested in recommending the presence of independent directors and enhancing the legitimacy of their presence in boards.

Within this research, we have estimated the independence of the directors in reference to the definition given in the report Button (2002). Certain factors can be considered as distorting the independence of the directors such as the relations of friendship between leaders and directors or the membership in associations, clubs which are except our field of investigation. It is the reason for which, we underline that the independence stays an estimate limited and dependent on criteria defined by the report Button (2002). We can add also that the criteria proposed by the report Button (2002) constitute conditions of independence but not a guarantee of independence. Certainly, the codes of corporate governance tried to give the characteristics of an independent director, by excluding the circumstances which could hinder its independence. The being purpose, to encircle better the notion of independence, but after all, the independence is other one than a moral quality to be satisfied by the director appointed by the shareholders to represent them.

\section{References}

Agrawal, A., \& Knoeber C R. (1996). Firm Performance and Mechanisms to control agency problems between managers and shareholder. Journal of Financial and Quantitative Analysis, 31(3): 377-397.

Albouy, M., \& Schatt, A. (2004). Les prises de contrôle par les actionnaires contestataires : Le cas André. Revue Finance Contrôle Stratégie, 7(2): 33-65.

Alexandre, H., \& Paquerot, M. (2000). Efficacité des structures de contrôle et enracinement des dirigeants. Finance Contrôle et Stratégie, 3: 5-29.

Bathala, T., \& Rao, R.P. (1995). The determinants of board composition: an agency theory perspective, Managerial and Decision Economics, 16: 59-69.

Baysinger, B., \& Buttler, H. (1985). Corporate governance and the board of directors: performance effects of changes in board composition. Journal of Law Economics and Organisation, 1: 101-124.

Borokhovich, K., Parrino, R., \& Trapani, T. (1996). Outside directors and CEO selection. Journal of Financial and Quantitative Analysis, 31: 337-362.

Brickley, J., Coles, J., \& Terry, R. (1994). Outside directors and the adoption of poison pills. Journal of Financial Economics, 35: 371-390.

Byrd, J., \& Hickman, K.A. (1992). Do outsider directors monitor managers. Journal of Financial Economics, 19: 589-606.

Charreaux, G. (1997). Conseil d'administration et pouvoirs dans l'entreprise . in Economica (Eds.), Le Gouvernement des Entreprises : Théorie et Faits: 141-164.

Charreaux, G., \& Pitol Belin, J.P. (1985). La théorie contractuelle des organisations, une application au conseil d'administration. Economies et Sociétés, 6: 149-181.

Charreaux, G., \& Pitol-Belin, J.P. (1990). Le conseil d'administration, Vuibert Gestion.

Cotter, J., \& Silvester, M. (2003). Board and monitoring committee independence. Abacus, 39 (2): 211 - 232.

Fama, E. (1980). Agency problems and the theory of the Firm. Journal of Political Economy, 88 (21): $288-307$.

Fama, E., \& Jensen, M. (1983). Separation of ownership and control. Journal of Law and Economics, 26: 195-235.

Gillan, S.L., \& Starks, LT. (2003). Corporate governance, corporate ownership, and the role of institutional investors: A global perspective. Journal of Applied Corporate Finance, 13 (2) : 4-22.

Godard, L. (1996). Conseil d'administration, stratégie et performance financière. Actes du XIII journées des IAE Toulouse: 158-174.

Godard, L. (2002). La taille du conseil d'administration: déterminants et impact sur la performance. Revue Sciences de Gestion, 33: 125-148.

Godard, L., \& Schatt, A. (2005). Caractéristiques et fonctionnement des conseils d'administration français. Un état des lieux. La Revue des Sciences de Gestion, 31 (158): 69-87.

Harris, M., \& Raviv, A. (1991). The theory of capital structure. Journal of Finance, XLVI (1): 291-355. 
Hermalin, B.E., \& Weisbach, M.S. (1988). The determinants of board composition, Rand Journal of Economics, 19: 589-606.

Jensen, M. (1986). Agency costs of free cash flow, corporate finance and takeovers. American Economic Review, 76: 323-329.

Jensen, M. (1993). The modern industrial revolution, exit, and the failure of internal control systems. Journal of Finance, 48: 831-880.

Jensen, M., \& Meckling, W.H. (1976). Theory of the firm; managerial behaviour, agency costs and ownership structure. Journal of Financial Economics, 4: 305-360.

KPMG. (2002). L'importance de la corporate gouvernance pour l'investisseur.

Le Maux, J. (2004). Les déterminants de l'ampleur des bénéfices privés : Un test sur les données françaises. Finance Contrôle Stratégie, 7 (2): 195-231.

Li, J. (1994). Ownership structure and board composition : A multi-country test of agency theory prediction. Managerial and Decision Economics, 15 (4): 359-368.

Mak, Y., \& Li, Y. (2001). Determinants of corporate ownership and board structure : evidence from Singapore. Journal of Corporate Finance, 17: 235-256.

McConnel, J., \& Serveas, H. (1995). Equity ownership and the two faces of debt. Journal of Financial Economics, 39: 131-157.

Mehran, H. (1995). Executive compensation structure, ownership and firm performance. Jounal of Financial Economics, 38: 163-184.

Pearce, J.A \& Zahra, S. (1992). Board composition from a strategic contingency perspective. Journal of Management Studies, 29 (4): 411-438.

Pound, J. (1988). Proxy contests and shareholder oversight. Journal of Financial Economics, 20: 237-265.

Prevost, A., Rao, R., \& Hossain, M. (2002). Board composition in new Zealand: An agency perspective. Journal of Business Finance and Accounting, 29 (5): 731-760.

Rapport Bouton. (2002). Pour un meilleur gouvernement des entreprises cotées, AFEP/AGREF, MEDEF.

Rapport Viénot. (1995). Le conseil d'administration des sociétés cotées, AFEP-CNFP.

Rapport Viénot. (1999). Rapport du comité sur le gouvernement d'entreprise, AFEP-MEDEF.

Rediker, K.J \& Seth, A. (1995). Boards of directors and substitution effects of alternative governance mechanism. Strategic Management Journal, 16: 85-99.

Rosenstein S. et Wyatt J.G. (1990). Outside directors, board independence and shareholder wealth. Journal of Financial Economics, 26: 175-191.

Weisbach, M.S. (1988). Outside directors and CEO turnover. Journal of Financial Economics, 20: 431-460.

Whidbee, D.A (1997). Board composition and control of shareholder voting rights in the banking industry. Financial Management, 26: 27-41.

Yermarck, D. (1996). Higher market valuation of companies with small board of directors. Journal of Financial Economics, 40: 185-211.

\section{Tables and Figures}

Table 1. Descriptive analysis of the variable PINDEP

\begin{tabular}{|c|c|c|c|c|}
\hline Year & Minimum & Maximum & Average & Standard deviation \\
\hline $\mathbf{1 9 9 9}$ & 0,000 & 0,818 & 0,281 & 0,199 \\
\hline $\mathbf{2 0 0 0}$ & 0,000 & 0,769 & 0,287 & 0,190 \\
\hline $\mathbf{2 0 0 1}$ & 0,000 & 0,846 & 0,291 & 0,194 \\
\hline
\end{tabular}

PINDEP: Percentage of independent directors 


\begin{tabular}{|c|c|c|c|c|c|c|c|c|}
\hline & PINDEP & BOARDSIZE & DUALITY & TENURE & COALITION & INSTIT & LEV & LGIZE \\
\hline PINDEP & 1 & & & & & & & \\
\hline BOARDSIZE & $0,349 * *$ & 1 & & & & & & \\
\hline DUALITY & 0,054 & $0,290^{* *}$ & 1 & & & & & \\
\hline TENURE & 0,011 & 0,003 & $-0,314^{* *}$ & 1 & & & & \\
\hline COALITION & $-0,506^{* * *}$ & $-0,123$ & $-0,004$ & $-0,072$ & 1 & & & \\
\hline INSTIT & $0,346^{* *}$ & 0,141 & $-0,078$ & 0,006 & $-0,272^{*}$ & 1 & & \\
\hline LEV & 0,128 & 0,208 & 0,173 & $-0,225^{*}$ & $-0,076$ & $0,385^{* * *}$ & 1 & \\
\hline LOGSIZE & $0,509^{* * *}$ & $0,659^{* * *}$ & 0,128 & $-0,051$ &,$- 358^{* * *}$ & 0,116 & $0,338^{* *}$ & 1 \\
\hline
\end{tabular}

$*, * *, * * * \mathrm{t}$ statistics are significant at $5 \%, 1 \%$ and $0.1 \%$ respectively

Panel B: Results for 2000

\begin{tabular}{|c|c|c|c|c|c|c|c|c|}
\hline & PINDEP & BOARDSIZE & DUALITY & TENURE & COALITION & INSTIT & LEV & LOGSIZE \\
\hline PINDEP & 1 & & & & & & & \\
\hline BOARDSIZE & $0,372^{* * *}$ & 1 & & & & & & \\
\hline DUALITY & $-0,043$ & $0,316^{* *}$ & 1 & & & & & \\
\hline TENURE & $-0,029$ & 0,001 & $-0,270^{*}$ & 1 & & & & \\
\hline COALITION & $-0,493^{* * *}$ & $-0,015$ & 0,178 & $-0,060$ & 1 & & & \\
\hline INSTIT & $0,350^{* *}$ & 0,130 & $-0,021$ & 0,021 & $-0,278^{*}$ & 1 & & \\
\hline LEV & 0,113 & 0,187 & $-0,030$ & $-0,150$ & 0,138 & $0,341^{* *}$ & 1 & \\
\hline LOGSIZE & $0,440^{* * *}$ & $0,665 * * *$ & 0,071 & $-0,054$ & $0,324^{* *}$ & 0,092 & $0,371^{* *}$ & 1 \\
\hline
\end{tabular}

$*, * *, * * * \mathrm{t}$ statistics are significant at $5 \%, 1 \%$ and $0.1 \%$ respectively

Panel C: Results for 2001

\begin{tabular}{|c|c|c|c|c|c|c|c|c|}
\hline & PINDEP & BOARDSIZE & DUALITY & TENURE & COALITION & INSTIT & LEV & LOGSIZE \\
\hline PINDEP & 1 & & & & & & & \\
\hline BOARDSIZE & $0,397^{* * *}$ & 1 & & & & & & \\
\hline DUALITY & 0,096 & $0,314^{* *}$ & 1 & & & & & \\
\hline TENURE & $-0,057$ & 0,024 & $-0,190$ & 1 & & & & \\
\hline COALITION & $-0,506^{* * *}$ &, 009 & 0,089 & $-0,057$ & 1 & & & \\
\hline INSTIT & $0,365^{* * *}$ & 0,126 & $-0,029$ & 0,017 & $-0,257^{*}$ & 1 & & \\
\hline LEV & 0,076 & 0,105 & $-0,072$ & $-0,062$ & 0,095 & $0,312^{*}$ & 1 & \\
\hline LOGSIZE & $0,446^{* * *}$ & $0,648^{* * *}$ & $-0,014$ & $-0,029$ & $-0,306^{* *}$ & 0,126 & $0,341^{* *}$ & 1 \\
\hline
\end{tabular}

$*, * *, * * * \mathrm{t}$ statistics are significant at $5 \%, 1 \%$ and $0.1 \%$ respectively 
Table 3. Results of the multiple linear Regressions

\begin{tabular}{|c|c|c|c|}
\hline $\begin{array}{l}\text { EXPLANATORY } \\
\text { VARIABLES }\end{array}$ & 2001 & 2000 & 1999 \\
\hline COALITION & $\begin{array}{c}-0,334 \\
(-3,692)^{* * *}\end{array}$ & $\begin{array}{c}-0,286 \\
(-3,058)^{* *}\end{array}$ & $\begin{array}{c}-0,271 \\
(-2,963)^{* *}\end{array}$ \\
\hline INSTIT & $\begin{array}{c}0,230 \\
(2,978)^{* *}\end{array}$ & $\begin{array}{c}0,242 \\
(2,883)^{* *}\end{array}$ & $\begin{array}{c}0,245 \\
(2,770)^{* *}\end{array}$ \\
\hline DUALITY & $\begin{array}{c}0,047 \\
(1,309)^{\mathrm{a}}\end{array}$ & $\begin{array}{c}-0,013 \\
(-0,340)\end{array}$ & $\begin{array}{c}0,019 \\
(0,462)\end{array}$ \\
\hline TENURE & $\begin{array}{c}-0,002 \\
(-0,664)\end{array}$ & $\begin{array}{c}-0,002 \\
(-0,728)\end{array}$ & $\begin{array}{c}0,000 \\
(-0,122)\end{array}$ \\
\hline LEV ERAGE & $\begin{array}{c}-0,212 \\
(-1,661)\end{array}$ & $\begin{array}{c}-0,233 \\
(-1,714)\end{array}$ & $\begin{array}{c}-0,221 \\
(-1,451)\end{array}$ \\
\hline LOGSIZE & $\begin{array}{c}0,096 \\
(3,650)^{* * *}\end{array}$ & $\begin{array}{c}0,095 \\
(3,616)^{* * *}\end{array}$ & $\begin{array}{c}0,104 \\
(4,119)^{* * *}\end{array}$ \\
\hline Constant & $\begin{array}{c}-0,216 \\
(-1,194)\end{array}$ & $\begin{array}{c}-0,189 \\
(-1,057)\end{array}$ & $\begin{array}{c}-0,265 \\
(-1,528)\end{array}$ \\
\hline $\mathrm{R}^{2}$ & $44,4 \%$ & $40,5 \%$ & $44,0 \%$ \\
\hline $\mathrm{R}^{2}$ adjusted & $39,3 \%$ & $35,6 \%$ & $39,3 \%$ \\
\hline $\mathrm{F}$ & $\begin{array}{l}9,593 \\
0,000\end{array}$ & $\begin{array}{l}8,185 \\
0,000\end{array}$ & $\begin{array}{l}9,430 \\
0,000\end{array}$ \\
\hline
\end{tabular}

Where:

PINDEP : is the ratio of the number of independent directors by the total number of directors on the board of directors

COALITION : Percentage of the capital represented by the coalition of control

INSTIT : participation of institutional investors

LEVERAGE :Level of Debt;

$D U A L I T Y$ : a dichotomous variable that takes the value 1 , if there is separation between the function of CEO and chairman of the board and 0 otherwise;

TENURE : CEO seniority ;

LOGSIZE : Size of the firm.

$a$ : is student $t$ statistic, *,**, *** t-statistics are significant at $5 \%, 1 \%$, and $0,1 \%$ respectively.

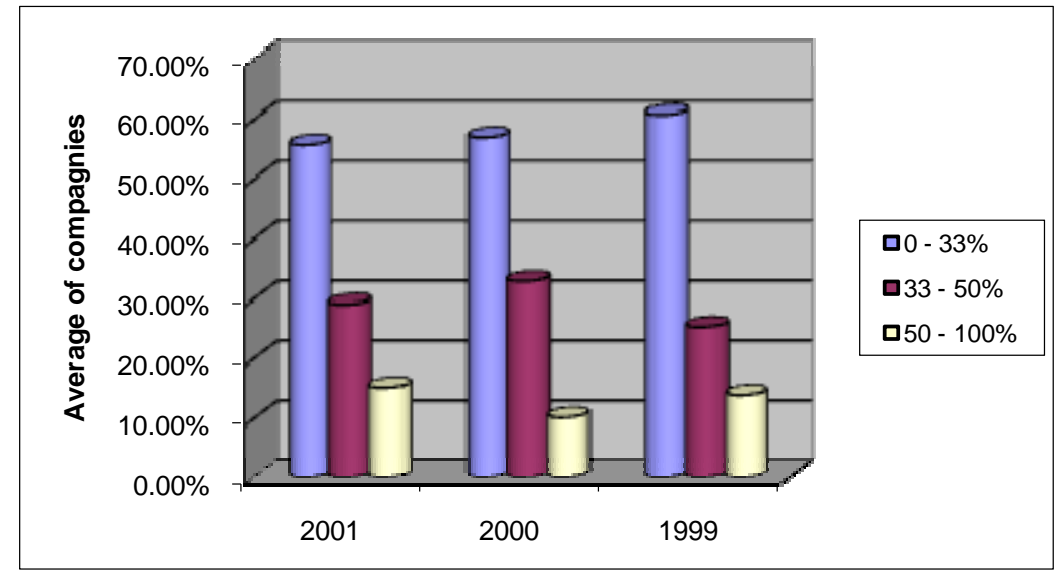

Figure 1. Independence of French boards from 1999 to 2001 